\title{
Editorial
}

\section{Audit committee member: Rent your own house}

The excitement felt last summer by those who thought that the long-awaited Disney decision had effectively stopped the movement to hold directors more liable for their actions - or rather, for their lack of them seems to be subsiding as the reaction sets in. The strongly worded appeal at the Delaware Chancery Court last month indicates that plaintiffs are not going to willingly allow directors to have a free pass on their fiduciary responsibilities on the argument that the business judgment rule shields them from what to a shareholder, if not a judge, seems to be the most egregiously incompetent behaviour.

Moreover, there is disagreement about the import of the case. Is the bent of the decision in upholding the business judgment rule overshadowed by the new good faith standard he hinted at in exercising the duty of care? In their fervour of excitement at the original trail finding, many corporate lawyers began touting the notion that by contemporaneous documentation of her thoughts, a director who has reservations about a company action could protect herself from liability. Unfortunately, the director may find herself alone when facing the torrents of litigation, the lawyer very probably being insulated from liability for the half-hearted advice proffered at $\$ 1,000$ an hour.

In the Enron and WorldCom cases, no director was adjudicated to be culpable of recklessness, the standard for liability in Private Securities Litigation Reform Act (PSLRA) cases, but the vagaries of the real world, the prospective exhaustion of insurance policy proceeds coupled with the inexhaustible deep pockets of institutional investors, forced independent directors into out-of-pocket settlements. And there is really no telling what constitutes recklessness under the PSLRA for independent director conduct or gross negligence under Delaware Law. In a 2002 paper, after the enactment of the Sarbanes-Oxley Act, the Chancellor and the Vice-Chancellor of the Delaware Chancery Court, including the author of the Disney decision, posited the notion that violations of the Act by officers and directors might be grounds for a derivative suit under Delaware corporate law. ${ }^{1}$ Delaware, however, is unlikely to be the driving force in corporate law reform through judicial decisions; neither is it likely to retard changes in corporate law and standards of directors' liability. As Professor Mark Roe of Harvard Law School has shown, Delaware courts work within the parameters of federal decisions and federal legislation. ${ }^{2}$ Indeed, for two years after the enactment of the SarbanesOxley Act almost all Delaware case rulings favoured the plaintiffs.

Consequently, time spent wasted on reading the tea leaves in the Disney case is counterproductive to understanding the future of officer and director liability. Nor need we wait for federal court cases adjudicating director recklessness in exercising the duty of care. The dynamics of the D\&O insurance settlement process coupled with institutional investor bounties for director 'out-of-pocket' settlements is all the impetus which the independent director should require to take his job seriously.

The real underlying problem is that even among audit committee members who wish to take their jobs seriously there is little guidance as to what that requires. In large measure, this is because they have been
International Journal of Disclosure and Governance, Vol. 3, No. 1, 2006, pp. 1-2 (c) Palgrave Macmillan Ltd 1746-6539/06 \$30.00 
pushed by CEOs and financial markets to offer 'big picture' strategic advice, rather than sticking with the unsexy job of verifying the financial statements. With my coauthors, I have enumerated a ten-point plan for audit committee members to tackle what has to go back to becoming their primary responsibility, which is to act as the trustees for the shareholders. ${ }^{3}$ These points, drawn from the analyses of ourselves and other leading contributors to the Journal, include the audit committee actually hiring and firing the auditor, not just following management recommendations; making its own determination about additional services audit firms may provide; managing the interaction between internal and external auditors at crucial junctures; seeking benchmarks to know if the company's performance is an outlier and being involved in issuing forecasts since this is where problems begin to arise. To carry out these responsibilities adequately, audit committees require independent legal and accounting advisers.

Unfortunately, very few if any audit committees have perceived their responsibilities in this light despite the fact that, in my estimation, the law demands as much. Moreover, in the absence of such a process as embodied in the ten points, institutional investors will show no mercy in going after independent directors when the chips are down and companies fall apart. Until inde- pendent directors can show a systematic approach to their audit committee responsibilities, they will be fair game for institutional investors and their PSLRA lawyers.

Those directors who continue to see serving on the audit committee in particular and the board in general as a sinecure rather than professional task can at least take solace in the settlements involving Lloyd's Names, when the anachronism of that amateurish system of risk management was finally revealed. Many of those well-meaning but naive members of the 'great and the good' had to surrender virtually all of their own assets but were at least allowed to occupy their own homes for their lifetimes.

\section{Mr John Friedland Editor}

\section{References}

1 Chandler, W. III and Strine, L. Jr. (2003) 'The new federalism of the American corporate system: Preliminary reflections of two residents of one small state', New York University Center for Law and Business Working Paper No. CLB 03-01.

2 Roe, M. J. (2003) 'Delaware's competition', Harvard Law Review, 117, 588.

3 Alles, M. G., Datar, S. M. and Friedland, J. H. (2005) 'Governance-linked D\&O coverage: Leveraging the audit committee', International Journal of Disclosure and Governance, 2(2), 114-129. 